\section{Cancer Research at Nottingham}

AT the annual meeting of the Court of Governors of University College, Nottingham, on December 15, under the presidency of His Grace the Duke of Portland, it was reported that a scientific research fellowship had been founded through the generosity of Mrs. Massey and Mrs. Massey Stewart. The purpose of the fellowship is to develop the physical methods for the diagnosis and cure of cancer. The Council appointed to this fellowship Dr. L. A. Woodward, who has had a distinguished career at Oxford and Leipzig. The local branch of the Imperial Cancer Campaign has made contributions of $\mathfrak{£ 5 0 0}$ for the purchase of additional instruments required and $£ 50$ to cover travelling expenses in connexion with the investigations. Accommodation has been found for the fellow in the Department of Physics, and the general equipment and facilities of the Department will be available for his use. The assistance of a biochemist in Dr. Woodward's work has been secured by the appointment of Dr. H. H. Barber, towards whose salary the Nottingham branch of the British Empire Cancer Campaign is contributing a sum of $£ 100$ a year for a period of three years in consideration of this assistance. A Joint Cancer Research Committee has been set up, consisting of the Principal, the heads of the Departments of Biology, Chemistry and Physics, and Dr. F. H. Jacob, Dr. R. G. Hogarth and Dr. A. M. Webber as representatives of the local branch of the British Empire Cancer Campaign.

\section{Science and War}

IN a speech delivered in the House of Commons on November 10, which has been reprinted by the New Commonwealth under the title "The Warning", the Right Hon. Stanley Baldwin deals with the moral and ethical consequences of the application of scientific discoveries or inventions to destructive purposes. Science has completely transformed the character and offensive powers of modern warfare. To the air attack there is no possible defence save in counter-attack, and aviation affords an outstanding example of an instrument of war the consequences of which are so terrible and deadly that the safety of mankind lies in the renunciation of its use. So far as the air is concerned, Mr. Baldwin agrees that only the abolition of flying offers any prospect of complete disarmament. Prohibition of the bombardment of the civil population and reduction of the size of aeroplanes are suggestions that are unlikely to stand the stern test of war. The abolition of flying is, however, an inconceivable step. Mankind has never yet consented to forego a new power which he has once claimed and the practical question which remains is the use to be made of this new power. Mr. Baldwin suggests that a thorough investigation of the problems involved in the international control of aviation is called for, apart altogether from the possibility of abolishing all air forces. Scientific workers should be among the first to respond to the moral appeal underlying $\mathrm{Mr}$. Baldwin's speech, that with the winning of new powers for mankind there should be won also a finer sense of moral responsibility and a determination to oppose the prostitution of such powers to base purposes. Only such a sense of values and of responsibility on the part of every individual citizen can save mankind from the destruction and disorder which seem the inevitable outcome of the present state of international relations.

\section{The Royal Dublin Society}

IT is recorded in the Irish Times of December 2 that Viscount Powerscourt has taken over the office of president of the Royal Dublin Society, in succession to Prof. J. Joly, whose term of office (three years) has come to an end. In the course of his Lordship's remarks, Lord Powerscourt, who is a leading member of the Agricultural Section of the Society, stated reasons for believing that the policy of the present governing body in Ireland must result in very grave effects upon the agricultural work of the Society. These fears are supported and very strongly emphasised by Dr. Bohane, the official director of the Society, in the Irish Times of December 3, whose remarks are mainly directed to financial considerations connected with the agricultural work of the Society. We are informed by Prof. Joly that the scientific work of the Society must also suffer seriously, seeing that the Society expends consider. able funds in support of scientific research and on the publication of its Scientific Proceedings and Transactions as well as on fees paid to experts who lecture upon scientific subjects in various rural districts of Ireland. The Irish Radium Institutewhich is legally affiliated to the Society-must also suffer, considering that the distribution of radium emanation devolves upon a senior and highly responsible member of its paid scientific staff. Those who wish for a full account of the Society's work at the present day will find it detailed by expert members of the Council in a volume issued recently in commemoration of the two-hundredth anniversary of its work for the prosperity of Ireland.

\section{Statistical Method of Control in Industry}

AN important aspect of the part which statistical method may play in industry in the improvement of the production process and in increasing efficiency in the fitting of supply to satisfy the wants of the consumer was discussed on December 20 at a meeting of the Royal Statistical Society, when Dr. E. S. Pearson contributed a paper on the statistical control of quality in mass-production industry. Whether the manufacturer is concerned with the tensile strength of malleable iron, the length of life of lamps, or the durability of cloth, he cannot succeed in producing exactly the same article again and again. Quality must, in fact, be expressed not only by an average but also by some measure of variation about this average. Yet if this is so, it is also important that there should be uniformity in this variation. For example, if the variability in the length of life in electric lamps can be reduced below a certain level, this may be of little value to the ordinary householder but a large-scale consumer such as a borough council may then find it a more economic proposition to

No. 3295 , VoL. 130] 